\title{
PROSTOROVÁ SEGREGACE EKONOMICKÝCH AKTIVIT
}

SPATIAL SEGREGATION OF ECONOMIC ACTIVITIES

\author{
ING. VladimíR ŽÍTEK, PH.D. \\ Katedra regionální ekonomie a správy $\quad$ Dep. of Regional Economics and Administration \\ Ekonomicko-správní fakulta Faculty of Economics and Administration \\ Masarykova univerzita Masaryk University \\ $\triangle$ Lipová 4la, 60200 Brno, Czech Republic \\ E-mail: zitek@econ.muni.cz
}

\begin{abstract}
Anotace
Využití půdy ve městě je do značné míry podmíněno základními vlastnostmi půdy, kterými jsou její jedinečnost a cena. Teorie si všimá především vztahu mezi požadovaným množstvím, cenou půdy a vzdáleností od centra (CBD). Základním přistupem $k$ využití půdy ve městě je Alonsův neoklasický model. Ten vychází z předpokladů Thünenova modelu izolovaného hospodářství. Popsané nedostatky Alonsova modelu řě́i sektorový a polycentrický model. Na př́kladu konkrétnich měst lze ověrit platnost těchto modeli̊. Město Vamberk plní řadu předpokladì Alonsova modelu, město Milevsko ve své struktuře koresponduje s parametry sektorového modelu.
\end{abstract}

\section{Klíčová slova}

využití půdy, prostorová segregace, bydlení, renta, rozvoj měst

\section{Annotation}

Land use in the city is considerably determined by basic characteristics of land that are its uniqueness and its rent. Theory pays attention especially on relation between demanded quantity, rent of land and distance from the centre (CBD). The Alonso neoclassical model is the basic approach to land use. It works on the assumption of the Thünen model of isolated economy. The described drawbacks of Alonso model are solved by the sector and the polycentric models. It is possible to verify validity of these models on the case of concrete municipalities. The city of Vamberk meets a lot of requirements of the Alonso model assumptions. The structure of the city of Milevsko corresponds with the sector model parameters.

\section{Key words}

land use, spatial segregation, housing, bid rent, municipal development

JEL classification: $R 52, R 12, R 14$

\section{Úvod}

Půda je výrobním faktorem, který je nepřemístitelný a jehož množství je limitováno, a to jak do rozsahu (množství), tak v možnosti způsobu využití. Obecně má půda různou podobu, jako jsou např́klad stavební pozemky, lesní a zemědělská půda, ale také louky, vodní zdroje či plochy nerostného bohatství. Cenou půdy je pozemková renta, která vyjadřuje prríjem vlastníka půdy plynoucí z jejího vlastnictví. Kucharčíková (2011) rozlišuje rentu na ekonomickou a kapitalizovanou. Zatímco ekonomická renta je představována nájemným z využívání půdy, kapitalizovaná renta je cenou půdy při jejím prodeji. Zkoumání půdy jakožto výrobního faktoru sahá k počátkům ekonomického myšlení. Relevantní teoretické koncepty, kdy je půda chápána jako faktor, který je možné substituovat ve výrobě, se objevily až v období vrcholícího merkantilismu, tedy v 17. století (Honová, 2009). Základ současného pojetí teorie půdy však přináší až klasická škola politické ekonomie, a to především v díle Adama Smithe, Thomase Roberta Malthuse a zejména Davida Ricarda. 
Smith považoval pozemkovou rentu za přebytek ceny nad náklady (tedy nikoliv za náklad), což vedlo $\mathrm{k}$ formulaci tvrzení, že zatímco mzdy (faktor práce) a zisky (faktor kapitál) jsou prŕčinou cen produkce, renta je jejich důsledkem. (Holman, 2005) Podle něj se renta mění nejen v závislosti na úrodnosti půdy, ale také s její polohou, kdy v blízkosti velkých měst je vyšší, než stejně úrodná půda v odlehlých částech území (Smith, 2001).

Malthus se domníval, že renta má dvě příčiny: 1) půda dává větší produkt, než potřebují rolníci pro svoji obživu; jde o dar př́rody vlastníkovi půdy, 2) půdy se liší přirozenou úrodností a vzdáleností od trhu. Maltusovy závěry odmítal Ricardo, který dospěl k poznání, že je to pouze rozdíl v kvalitě a množství půdy, které diferencují pozemkovou rentu (Honová, 2009). Renta vzniká z rozdílných výnosů kapitálů, které jsou vloženy do různě úrodných půd. Obecně pak platí, že každá půda vynáší rentu, jejíž velikost je dána rozdílem mezi její výnosností a výnosnosti půdy, kterou se ještě vyplatí obdělávat (přináší alespoň nulový ekonomický zisk). Je třeba ještě zdůraznit, že výnosnost je ovlivněna nejen vlastní úrodností, ale také polohou, resp. vzdáleností od trhu. Ricardova teorie diferenční pozemkové renty je $\mathrm{z}$ dnešního pohledu pouze speciálním př́ípadem teorie mezní produktivity, kterou později formuloval Johann Heinrich von Thünen. (Holman, 2009)

\section{Thünenenův model izolovaného hospodářství}

Thünen vycházel z abstraktního modelu izolovaného hospodářství (státu), které je vymezeno následujícími parametry (Maier, Tödtling, 1997; Belajová, Fáziková, 2005):

- existuje ekonomický prostor izolovaný od okolí, který se nachází na homogenní ploše,

- všichni spotřebitelé jsou v jednom místě, kde jsou obchodovány všechny produkty,

- všichni výrobci mají stejné produkční funkci pro stejné produkty,

- dopravní spojení je ze všech stran stejné, neexistují žádné překážky,

- dopravní náklady jsou rozdílné pro různé produkty.

Je tedy zřejmé, že výrobci při jejich obecné snaze maximalizovat zisk a při vědomí dokonalé mobility kapitálu mohou zaplatit za pronájem maximálně částku rovnající se polohové rentě. Její výše závisí na dopravních nákladech, na produkovaném statku (naléhavostí spotřeby, resp. nároky na jakost produktu) a tržní ceně. (Ježek, 2002) Platí tedy, že v blízkosti trhu je půda využívána k produkci plodin, které jsou ziskovější a jejich doprava nákladnější. S rostoucí vzdáleností od centra se pak půda využívá postupně pro zemědělské aktivity s nižší ziskovostí, které mají nižší dopravní náklady. Stejné produkce nemohou být umístěny ve výrazně jiných lokalitách. (Čadil, 2010) Jednotlivé zóny zemědělské výroby znázornil Thünen v podobě koncentrického modelu (viz obr. 1). Stř̌ed tvoří vlastní centrum sídla s trhem a následují postupně další zóny.

\section{Neoklasická Land Use teorie}

Nejvýznamnější oblastí aplikace Thünenenova modelu se z dnešního pohledu jeví teorie prostorové struktury měst, jejímž základem je neoklasická ekonomická analýza. Představitelem, s nímž jsou spojovány počátky tohoto konceptu je W. Alonso (1964), který při rozdělování jednotlivých aktivit uskutečňovaných v rámci města využil právě Thünenův koncentrický model. Neoklasický model využití půdy je vystaven na stejných předpokladech, jako je homogenní prostor, dokonalé informace o trhu, snaha o maximalizaci zisku či užitku, s drobnou terminologickou odlišností: veškeré tržní transakce se odehrávají v centru, které označuje jako central business district (CBD), pozemkovou rentu pak označuje jako bid rent (Maier, Čtyřoký, 2000; Belajová, Fáziková, 2005).

Základním prvkem alokačního mechanismu tohoto modelu je trade off mezi velikostí pozemku (ale fakticky bid rent) a vzdáleností od centra (tedy dopravními náklady). Neoklasická teorie tedy využívá mechanismu mikroekonomické analýzy chování spotřebitele (např. Samuelson, Nordhaus, 1991), v jejíž grafické podobě existují stejné úrovně užitku (indiferenční křivky) při různých kombinacích vzdálenosti pozemku a výše pozemkové renty. Nastavení hladiny užitku je individuální a odvíjí se od 
výše prŕíjmu domácnosti a výše výdajů na běžnou spotřebu. (Čadil, 2010) Po odečtení výdajů na běžnou spotřebu má domácnost $\mathrm{k}$ dispozici př́ijmy, které dělí mezi rentu (nájemné) a dopravní náklady (náklady na překonání vzdálenosti). Je tedy logické, že platí elementární pravidlo: s rostoucí vzdáleností klesá nájemné na $\mathrm{m}^{2}$.

Na základě vztahu mezi požadovanou velikostí bydlení a částky, kterou má domácnost $\mathrm{k}$ dispozici, lze konstruovat její bid rent křivku (Sýkora, 1993). Křivka bid rent představuje množinu kombinací výše renty (nájmu) a vzdálenosti, při kterých daná domácnost maximalizuje svůj užitek. Sklon křivky bid rent je dán velikostí př́ijmu domácnosti, přičemž platí, že domácnost s nižšími př́ijmy je ochotná $\mathrm{v}$ centru (při nulové vzdálenosti) platit vyšší rentu za $\mathrm{m}^{2}$, než domácnost $\mathrm{s}$ vyššími př́ijmy. To je dáno spotřebitelským očekáváním obou domácností, kdy domácnost $\mathrm{s}$ vyššími př́ijmy požaduje v rámci maximalizace svého užitku větší plochu, než domácnost s nižšími příjmy.

Uvedený neoklasický model je možné rozšířit, jak již bylo uvedeno, také na vysvětlení využití půdy ve městě pro různé aktivity (funkce). Východiska jsou přitom shodná. Jelikož nejsou domácnosti schopné konkurovat průmyslové výrobě, resp. obecně podnikatelským subjektům, které jsou schopny z jednotky plochy získat vyšší zisk v porovnání s užitkem domácností, mohou reálně získat méně výhodně položené pozemky, než obchodní a průmyslové subjekty (Belajová, Fáziková, 2005). Připomeňme, že je to způsobeno strmostí křivek bid rent, kdy pro některé ekonomické činnosti klesá ziskovost se vzdáleností od centra (CBD) velmi prudce, naopak jiné se stávají s rostoucí vzdáleností konkurenceschopnější. To velmi dobře ukazuje následující obrázek, znázorňující prostorové rozložení obchodní zóny $\left(\mathrm{R}_{\mathrm{o}}\right)$, průmyslové zóny $\left(\mathrm{R}_{\mathrm{p}}\right)$, zóny bydlení $\left(\mathrm{R}_{\mathrm{b}}\right)$ a zóny zemědělské výroby $\left(\mathrm{R}_{\mathrm{z}}\right)$.

\section{Obr. 2: Alonsův model struktury města}

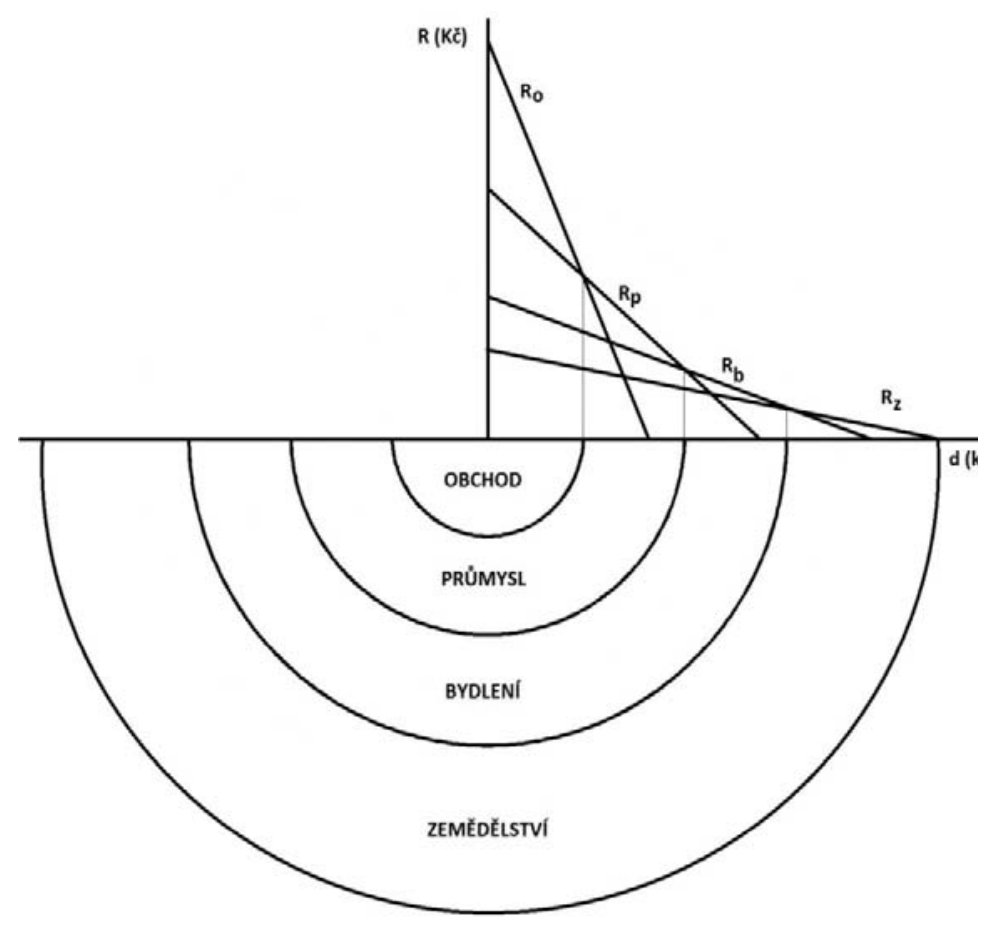

Zdroj: Belajová, Fáziková, 2005 (doplněno a přepracováno)

Alonsův model přes nesporný přínos pro vysvětlení podstaty rozmístění ekonomických aktivit ve městě má řadu omezení. Na první pohled jsou zrejemé především dvě:

- struktura měst je reálně značně diferencovaná př́rodními danostmi, jako jsou nerovný terén, existence vodních toků, heterogenita půdy a následně vzniklou základní infrastrukturou liniových komunikací (zejména silnic),

- už města střední velikosti jsou charakteristická tím, že mají více center (zejména v důsledku historického spojení více menších sídel do jednoho města, př́padně v důsledku vzniku nových obchodních center na zelené louce), nikoliv jen jedno, jak předpokládá Alonso. 


\section{Sektorový a polycentrický model}

Řešení uvedených omezení Alonsova modelu nabízí sektorový model, jehož autorem je Homer Hoyt (1939) a model více (mnoha) jader (polycentrický model).

\section{Obr. 3: Hoytův sektorový model}

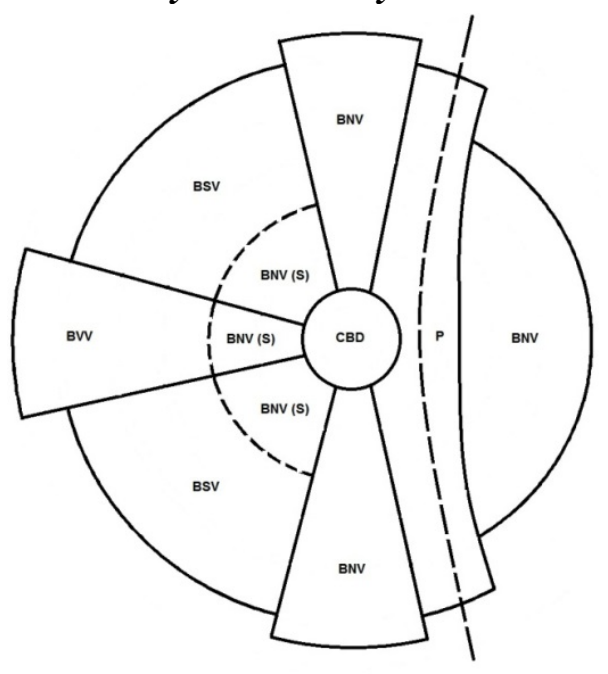

CBD central business district

P obchodní a průmyslová zóna, kterou prochází hlavní komunikace

BVV bydlení vyšších společenských vrstev

BVS bydlení středních společenských vrstev

BNV bydlení nižších společenských vrstev

BNV-S bydlení nižších společenských vrstev, území s probíhající sociální segregací

Zdroj: Ježek, 2002; Maier, Čtyřoký, 2000 (upraveno)

Hoytův model zohledňuje vliv přírodních podmínek a lidské činnosti ovlivňující sociální segregaci, ale především existenci hlavní komunikace, kterou může být například řeka, později železniční trasa a v současnosti zejména silniční tah. (Ježek, 2002; Maier, Čtyřoký, 2000)

Naproti Alonsovu modelu polycentrická teorie odráží skutečnost, že současná města mají více center, která vznikla bud' zcela přrirozeně splynutím měst, jejichž hranice se v důsledku rozvoje postupně přibližovaly, či vdůsledku působení tržních sil, kdy nová centra vznikla na zelené louce jako přirozený důsledek přetížení infrastruktury vnitřních částí města. Jiným důvodem vzniku center na zelené louce je také posun od prostředí diferencovaného infrastrukturními faktory (více o roli faktorů Viturka 2011) ke struktuře ovlivněné preferencí prvků znalostní ekonomiky, na které je kladem v současnosti značný důraz (Klímová 2012). Alternativně mohou sekundární centra vznikat jako důsledek územního plánování, kdy do tržního mechanismu vstupuje faktor společenského užitku, v důsledku jehož působení usiluje územní samospráva o vznik nových center se všemi souvisejícími ekonomickými důsledky.

\section{Obr. 4: Polycentrický model}

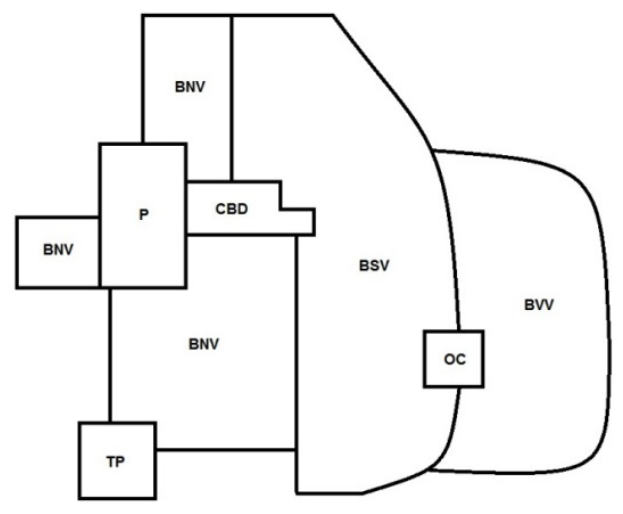

CBD central business district

P obchodní a průmyslová zóna

BVV bydlení vyšších společenských vrstev

BVS bydlení středních společenských vrstev

BNV bydlení nižších společenských vrstev

OC obchodní centrum

TP těžký průmysl 


\section{Ověření modelů využití půdy ve městě}

Teoretické koncepty působí většinou velmi strnule a jsou postaveny na řadě omezení či předpokladů. Pokud jde o prostorovou segregaci ekonomických aktivit ve městech, lze ji na konkrétních př́kladech porovnat se závěry popsaných modelů. Za tímto účelem byla vybrána města Vamberk (Královehradecký kraj, cca 5 tis. obyv.) a Milevsko (Jihočeský kraj, cca 9 tis. obyv.). Přestože města byla vybrána náhodně, splňují určitá kritéria. Především mají dostupný aktuální územní plán, plní komplexní spektrum funkcí a jde o města menší velikosti (Město Vamberk, 2013; RERA (2007).

Město Vamberk leží na křižovatce silnic první třídy č. 11 a č. 14 (žluté čáry). Právě tyto komunikace do značné míry ovlivnily rozvoj města a vytvoření stávajícího systému funkčního využití půdy. V současnosti je veškerá tranzitní doprava přeložena díky obchvatu (silnice č. 11) z velké části mimo město. Tím také došlo k přsesunutí křižovatky se silnicí č. 14 na hranici města. Železniční trasa (fialová čára) prochází severní částí města, není př́liš vzdálena od jeho centra.

Pokud jde o rozložení funkčních zón, splňuje Vamberk do značné míry parametry Alonsova modelu. CBD tvoří centrum služeb města, bezprostředně navazují průmyslové zóny, resp. zóny výroby a skladování. Zóna bydlení však nenavazuje na průmysl bezprostředně, patří ji spíše východní, ale částečně také severní a jižní část města. Pokud jde o potvrzení koncentrace př́ijmově odlišných skupin obyvatelstva, jsou bytové domy (kde očekáváme spíše obyvatelstvo s nižšími prřímy) alokovány částečně blízko centru, ale také ve vzdálenější poloze. Nové rozvojové plochy, kde lze předpokládat př́ijmově nejsilnější obyvatelstvo, jsou v souladu s teorií na východním okraji katastrálního území Vamberka. Zemědělská výroba se nachází v zóně nejvíce vzdálené od centra.

\section{Obr. 5: Územní plán města Vamberk}

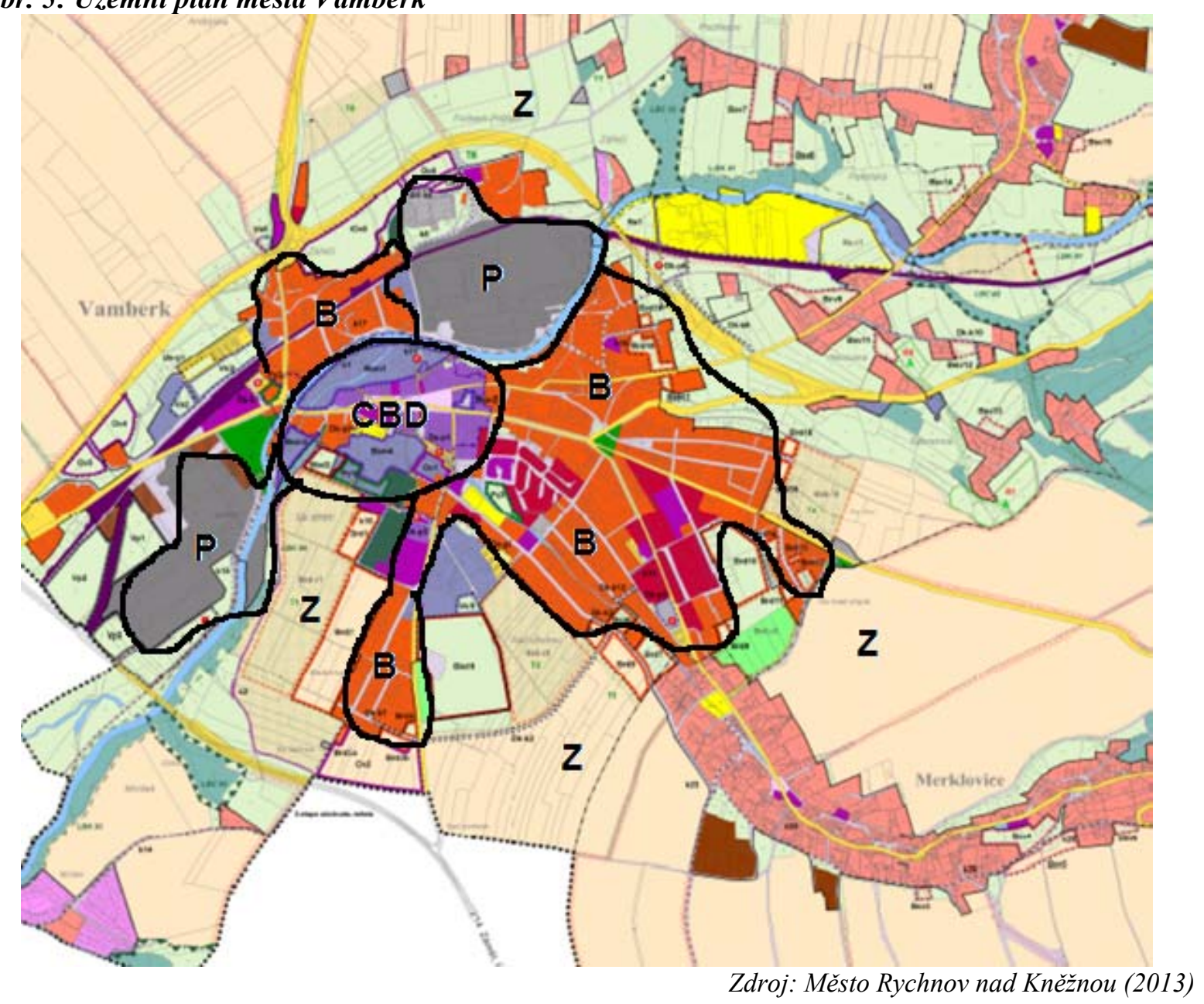


Město Milevsko leží v bezprostřední blízkosti silnice první třídy č. 19 (přerušovaná čára), které prochází po severní, severovýchodní a východní hranici města. Železniční trasa (šedý pruh) se dotýká města na jeho jihovýchodní hranici, nádraží leží v relativně odlehlé částí, daleko od centra města.

Při pohledu na město Milevsko lze vidět výraznou shodu rozložení ekonomických aktivit s prredpoklady Hoytova sektorového modelu. Výjimkou je pouze průmyslová výroba, která je převážně lokalizována $\mathrm{v}$ blízkosti železnice a hlavní silnice (tedy na severním, SV, východním a JV okraji města). CBD leží př́ímo na původní páteřní komunikaci, je tvořeno zónou služeb a smíšenou zónou (služby a bydlení), která je významně poznamenána chybnými architektonickými rozhodnutími z 2. poloviny 20. století. Celé CBD je pak obklopeno zónami bydlení různých úrovní, které jsou doplněny službami (především občanská vybavenost) a rekreace (hřiště). Př́ijmově nejvyšší zóny lez předpokládat zejména $\mathrm{v}$ rozvojových zónách na západním okraji města, ale také $\mathrm{v}$ pásech vycházejících z CBD směrem $\mathrm{k}$ těmto rozvojovým zónám, ale také východním směrem, kde jsou oblasti s výrazně modernizovanými rodinnými domy. Obyvatelstvo s nižšími př́ijmy v bytových domech je koncentrováno částečně v SV zóně navazující na CBD a pak významně v JV zóně, které leží mezi CBD a průmyslovou oblastí v okolí železniční trasy.

\section{Obr. 6: Územní plán města Milevsko}

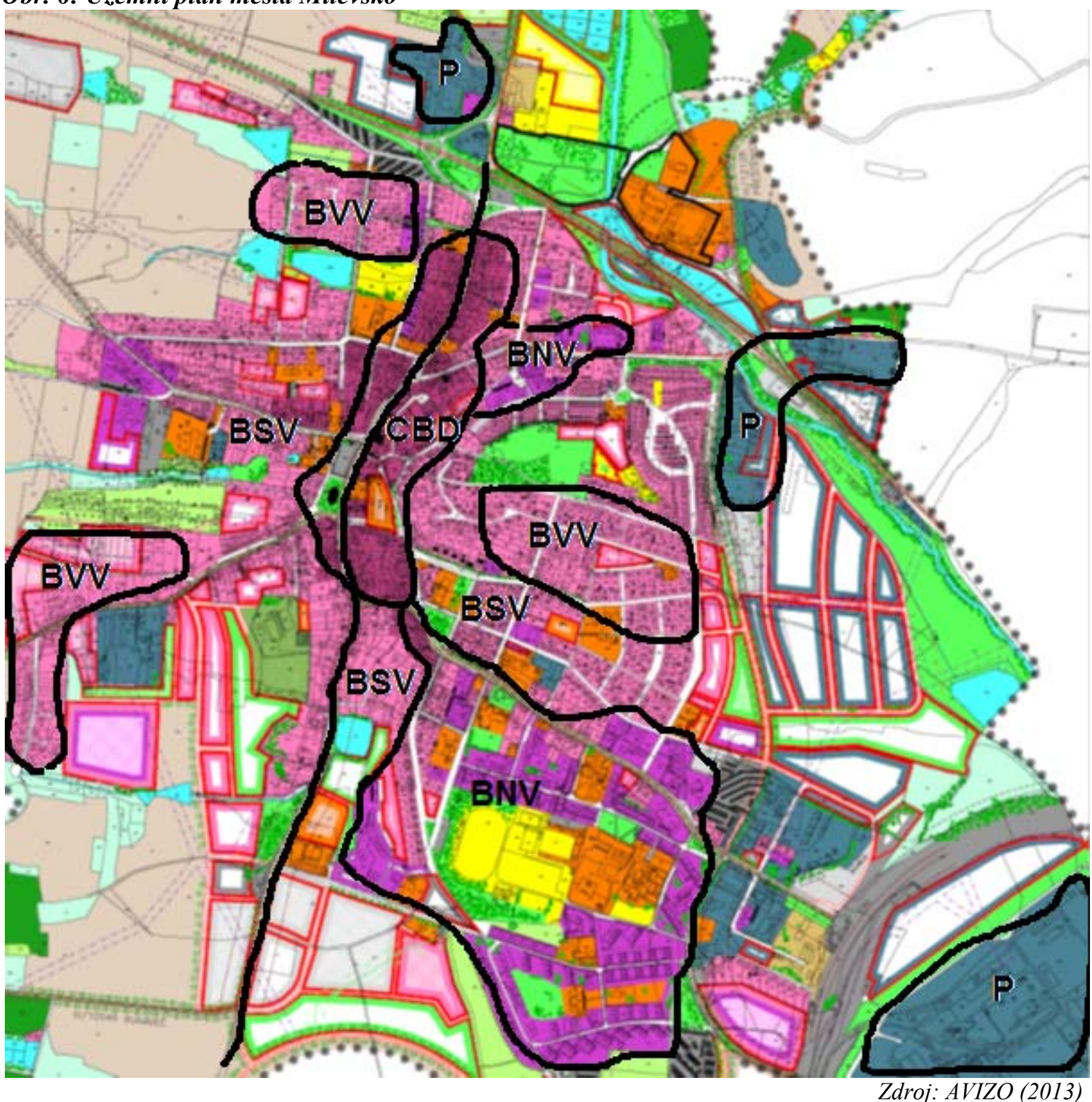

Zdroj: $A V I Z O(2013)$ 


\section{Závěr}

Půda je specifickým faktorem. Její dominantní charakteristika, kterou je jedinečná poloha, do značné míry předurčuje její využitelnost. Teoretické koncepty od samého počátky, kdy se půda stala objektem zájmu vědy, si všímají jejího limitní ho množství a její ceny, kterou je renta, nebo také bid rent. Využití půdy je relevantním způsobem popsáno Thünenovým modelem izolovaného hospodářství. Nejvýznamnější oblastí aplikace tohoto modelu se z dnešního pohledu jeví teorie prostorové struktury měst, jejímž základem je neoklasická ekonomická analýza a zakladatelem Alonso. Základním prvkem alokačního mechanismu tohoto modelu je trade off mezi velikostí pozemku (ale fakticky bid rent) a vzdáleností od centra (CBD). Alonsův model má však svá omezení, jejichž řešení nabízí sektorový model a model polycentrický. Uvedené modely je do značné míry možné ověřit na př́íkladu konkrétních měst. Město Vamberk naplňuje většinu předpokladů Alonsova modelu s tím, že zóny nejsou rovnoměrně koncentrické. Město Milevsko naproti tomu významně koresponduje s předpoklady Hoytova sektorového modelu, snad jen s výjimkou průmyslu odkloněného od CBD.

\section{Literatura}

[1] AVIZO. Územni plán města Milevsko. [cit. 25.4.2013] Dostupný z: $<$ http://www.ecpm.cz/cz/detail-uzemniho-planu/24-milevsko-uzemni-plan>.

[2] BELAJOVÁ, A., FÁZIKOVÁ, M. Regionálna ekonomika. Nitra: Slovenská pol’nohospodárska univerzita, 2005.

[3] ČADIL, J. Regionální ekonomie. Teorie a aplikace. Praha: C. H. Beck, 2010.

[4] HAMALOVẢ, M. a kol. Priestorová ekonomika. Bratislava: Ekonóm, 1996.

[5] HOLMAN, R. a kol. Dějiny ekonomického myšlení. Praha: C. H. Beck, 2005.

[6] HONOVÁ, I. Půda z pohledu dějin ekonomických teorií. Politická ekonomie, 6, 2009, str. 827841.

[7] JEŽEK, J. Prostorová a regionálni ekonomika. Plzeň: Západočeská univerzita, 2002.

[8] KLÍMOVÁ, V. Znalosti jako faktor dlouhodobé konkurenceschopnosti. In Udržitelný rozvoj a funkce moderniho evropského státu. České Budějovice: Vysoká škola evropských a regionálních studií, 2012. s. 56-61.

[9] KUCHARČÍKOVÁ, A. a kol. Efektivni výroba. Praha: CPress, 2011.

[10] MAIER, G., TÖDTLING, F. Regionálna a urbanistická ekonomika. Teória lokalizácie a priestorová struktura. Bratislava, Elita, 1997.

[11] MAIER, K., ČTYŘOKÝ, J. Ekonomika územniho rozvoje. Praha: Grada Publishing, 2000.

[12] Město Rychnov nad Kněžnou . Územní plán města Vamberk, 2013. Dostupný z: $<$ http://www.rychnov-city.cz/uzem_plan/vamberk_up/urban-cast.pdf $>$.

[13] Město Vamberk (2013). [cit. 25.4.2013] Dostupný z: <http://www.vamberk-city.cz>.

[14] RERA. Strategie rozvoje města Milevsko, 2007. [cit 25.4.2013] Dostupný z: $<$ http://www.rera.cz/index.php?documentID $=273>$.

[15] SAMUELSON, P. A., NORDHAUS, W. D. Ekonomie. Praha: Svoboda, 1991.

[16] SMITH, A. Pojednání o podstatě a bohatství národi̊. Praha: Liberální institut, 2001.

[17] SÝKORA, L. Teoretické př́stupy ke studiu města. In Sýkora, L. (ed.) Teoretické př́stupy a vybrané problémy v současné geografii. Praha: Univerzita Karlova, 1993, str. 64-99.

[18] VITURKA, M. Změny kvality podnikatelského prostředí podle českých krajů a správních obvodů ORP v období 2001/2002 - 2006/2008. In Klimová, V., Žítek, V. (eds.) XIV. mezinárodni kolokvium o regionálních vědách. Sborník př́spěvků. Brno: Masarykova univerzita, 2011. s. 19-24, 6 s. ISBN 978-80-210-5513-1. 